\title{
GAMBARAN PENGGUNAAN INTERNET DALAM PENCARIAN INFORMASI TENTANG HIV DAN AIDS PADA REMAJA
}

\section{DESCRIPTION OF THE USE OF THE INTERNET IN SEARCHING INFORMATION ABOUT HIV AND AIDS IN YOUTH}

\author{
Herlin Fitriani Kurniawati ${ }^{1}$, Herlin Fitriana Kurniawati ${ }^{2}$ \\ ${ }^{1}$ Program Studi Pendidikan Profesi Bidan, ${ }^{2}$ Program Studi Sarjana Terapan Kebidanan \\ Email : risanindira@gmail.com
}

\begin{abstract}
ABSTRAK
HIV merupakan salah satu penyakit menular yang dikelompokkan sebagai faktor yang dapat mempengaruhi kematian. Penderita HIV/AIDS yang sebelumnya merupakan orang dewasa, kini mulai bergeser menjadi remaja berusia 20-24 tahun. Tujuan dari penelitian ini untuk mengetahui gambaran Penggunaan Internet Dalam Pencarian Informasi Tentang HIV dan AIDS Pada Remaja. Metode penelitian menggunakan pendekatan kualitatif. Subjek penelitian ini adalah remaja yang mengakses informasi tentang HIV dan AIDS menggunakan media internet minimal dalam 6 bulan terakhir dan bersedia untuk menjadi responden. Hasil penelitian didapat pengetahuan tentang HIV dan AIDS masih kurang terutama pada tanda dan gejala serta penularan, masih terdapat stigma terhadap orang dengan HIV dan AIDS. Semua informan mengatakan mendukung dalam pencarian informasi tentang HIV dan AIDS melalui media internet. Semua informan mengatakan akses dalam pencarian informasi tentang HIV dan AIDS sangatlah mudah, biaya dalam pencarian informasi tentang HIV dan AIDS terjangkau. Semua informan mengatakan menggunakan internet atas inisiatif sendiri, sebagian besar informan mengatakan menggunakan internet kurang lebih 2-5 jam perhari, rata-rata menggunakan internet sejak lebih dari 2 tahun yang lalu. Sebagian besar responden mengatakan sudah pernah mencari informasi mengenai HIV dan AIDS walaupun tidak intens hanya apabila mereka membutuhannya. Saran bagi kader kesehatan diharapkan dapat mengusulkan untuk pembentukan Bina Keluarga Remaja (BKR) atau Pusat Informasi dan Konseling Kesehatan Reproduksi Remaja (PIK-KRR) dengan bekerja sama dengan Kecamatan dan BKKN Kabupaten.
\end{abstract}

Kata kunci : HIV dan AIDS, Internet, Remaja

ABSTRACT

HIV is an infectious disease that is classified as a factor that can affect death. HIV/ AIDS sufferers who were previously adults, are now beginning to shift to adolescents aged 20-24 years. The purpose of this study is to find out an overview of internet usage to search an information about HIV and AIDS. The research method uses a qualitative approach. The subjects of this study were teenagers who accessed information about HIV and AIDS using the internet for at least the last 6 months and were willing to become respondents. The results show that knowledge about HIV and AIDS is still lacking, especially in the signs and symptoms and transmission, there is still a stigma against people with HIV and AIDS. All informants said that they supported the search for information about HIV and AIDS through internet media. All informants said that access to information about HIV and AIDS was very easy, the costs of finding information about HIV and AIDS were affordable. All informants said that using the internet on their own initiative, most of the informants said that using the internet was approximately 2-5 hours a day, on average using the internet more than 2 years ago. Most respondents said that they had sought information about HIV and AIDS even if they were not intense only if they needed it. Suggestions for health cadres are expected to be able to propose the formation of Adolescent Family Development (BKR) or the Adolescent Reproductive Health Counseling Center (PIK-KRR) in collaboration with the District and BKKN District.

Keywords : HIV and AIDS, internet, Adolescents 


\section{PENDAHULUAN}

Perkembangan permasalahan HIV dan AIDS (Human Immuno Deficiency VirusAcquiredImmune Deficiency Syndrome) semakin lama semakin mengkhawatirkan baik dari sisi kuantitatif maupun kualitatif. Indonesia menjadi negara urutan ke lima di Asia paling beresiko HIV/AIDS. HIV merupakan salah satu penyakit menular yang dikelompokkan sebagai faktor yang dapat mempengaruhi kematian. Jumlah kasus HIV \&AIDS yang tercatat sebenarnya jauh lebih kecil dari prevalensi sesungguhnya sebagai fenomena Gunung Es (Kemenkes RI, 2011).

Berdasarkan data Direktorat Jenderal Pencegahan dan Pengendalian Penyakit Kemenkes RI (2016) Laporan Perkembangan Tri wulan 1 (Januari Maret) tahun 2016 didapatkan hasil bahwa jumlah kasus HIV yang dilaporkan sebanyak 7.146 orang, sedangkan untuk kasus AIDS sebanyak305 orang. Secara kumulatif kasus HIV dan AIDS dari 1 April 1987 sampai dengan Maret 2016 sebanyak 198.219 kasus HIV dan 78.292 kasus AIDS. Persentase infeksi HIV tertinggi dilaporkan pada kelompok umur 25-49 tahun (69,7\%), kelompok umur 2024 tahun $(16,6 \%)$, dan kelompok umur $\geq$ 50 tahun (7,2\%). Sedangkan untuk persentase AIDS tertinggi pada kelompok umur 30-39 tahun (37,7\%), kelompok umur 20-29 tahun $(29,9 \%)$ dan kelompok umur 40-49 tahun (19\%). Persentase faktor risiko HIV tertinggi adalah hubungan seks berisiko pada heteroseksual (47\%), Lelaki Seks Lelaki (LSL) (25\%), lain-lain (25\%), pengguna jarum suntik tidak steril pada pengguna narkotika suntik (3\%). Persentase faktor risiko AIDS tertinggi adalah hubungan seks berisiko pada heteroseksual $(73,8 \%)$, Lelaki Seks Lelaki (LSL) (10,5\%), pengguna jarum suntik tidak steril pada pengguna narkotika suntik $(5,2 \%)$ dan perinatal $(2,6 \%)$. Hal tersebut menunjukkan faktor risiko HIV dan AIDS didominasi dengan hubungan seks berisiko pada heteroseksual.
Kasus HIV dan AIDS pertama kali di Indonesia dilaporkan Departemen Kesehatan Republik Indonesia pada tahun 1987. Pada awal perkembangannya pola penularan didominasi oleh homoseksual dan heteroseksual, mulai tahun 1995 sampai dengan Maret 2005 proporsi penularan melalui kelompok pengguna napza suntik meningkat dari 0,65\% menjadi 35,87\% (KPA, 2008).

Perhimpunan Dokter Spesialis Kulit dan Kelamin Provinsi Daerah Istimewa Yogyakarta (PERDOSKI DIY) mengungkapkan penderita HIV/AIDS yang sebelumnya merupakan orang dewasa, kini mulai bergeser menjadi remaja berusia 20-24 tahun. Secara nasional jumlah penderita HIV dan AIDS masih sedikit dibandingkan daerah-daerah lain di Indonesia atau kota besar lainnya, akan tetapi yang memprihatin adalah dengan meningatnya kasus penderita HIV dan AIDS di kalangan remaja DIY. Terjadi peningkatan jumlah kasus baru penderita penyakit yang menyerang sistem kekebalan tubuh itu, sejak beberapa tahun terakhir. Guna mengantisipasi penyebaran penyakit ini di kalangan remaja yang lebih luas lagi, PERDOSKI DIY melakukan sejumlah penyuluhan bagi kalangan pelajar, khususnya yang saat ini tengah duduk di bangku Sekolah Menengah Atas (Dwianjani, 2016).

DIY menyimpan sebuah permasalahan yang harus segera ditangani serius oleh pemerintah. Karena budaya seks bebas di kalangan remaja yang kian meningkat mengakibatkan sejumlah remaja berpotensi terjangkit HIV/AIDS. Pemberian informasi yang diikuti dengan penjelasan secara mendalam mengenai penyakit IMS serta HIV dan AIDS dan penularannya ini, bertujuan memberikan pengetahuan dan pemahaman akan bahayanya seks bebas serta dua penyakit tersebut. Hal tersebut dilakukan dengan harapan agar ke depan kalangan remaja lebih memahami bagaimana penularan HIV/AIDS, agar perkembangan jumlah penderita HIV/AIDS bisa terus ditekan. 
Berdasarkan data PKBI Kabupaten Kulon Progo ditemuan bahwa kasus HIVAIDS di Kabupaten Kulon Progo mengalami trend peningkatan. Dari yang tadinya 158 pada 2015 sampai dengan November 2016 jumlahnya bertambah menjadi 177 kasus.Sementara jumlah tersebut diperkirakan akan terus bertambah seiring dengan perubahan pola kehidupan dan kemajuan sebuah daerah. Setidaknya semua kecamatan di Kabupaten Kulon Progo, ditemukan adanya kasus pengidap virus HIV-AIDS.

Untuk mengendalikan penularan dan pencegahan, KPA terus melakukan beberapa upaya pencegahan mulai dari sosialisasi, pendampingan hingga beberapa upaya pencegahan. Tidak hanya di kalangan masyarakat, tetapi juga menyentuh pelajar melalui pendidikan reproduksi. Masih rendahnya pengetahuan remaja menjadikan masalah terhadap penanganan kasus HIV dan AIDS, dimana ada periode tersebut merupakan periode mencoba-coba.

Bandara baru yang akan dibangun di Kecamatan Temon Kulon Progo akan berdampak bagi seluruh aspek kehidupan dikalangan masyarakat, sehingga dibutuhkan kajian dan diskusi untuk memetakan masalah yang ditimbulkan dari pembangunan bandara tersebut, termasuk juga isu terkait tentang HIV dan AIDS. Bandara yang hendak dibangun sedikit banyak berpengaruh terhadap kondisi masyarakat dan memberikan tantangan terbaru bagi masyarakat, sehingga perlu adanya solusi dari permasalahan tersebut. Untuk mengatasi hal tersebut maka diperlukan strategi yang tepat untuk mengatasinya salah satunya dengan pemberian informasi tentang HIV dan AIDS melalui aplikasi wahtsapp group.

Dewasa ini komunikasi sangat diperlukan dalam semua aspek kegiatan manusia. Dengan komunikasi manusia dapat mengekspresikan gagasan, perasaan, harapan dan kesan kepada sesama serta memahami gagasan, perasaan, dan kesan orang lain. Komunikasi tidak hanya mendorong perkembangan kemanusiaan, namun juga menciptakan hubungan sosial yang sangat diperlukan dalam kelompok sosial apapun. Komunikasi memungkinkan terjadinya kerjasama sosial, membuat kesepakatan - kesepakatan penting dan lain sebagainya.

Pesatnya perkembangan teknologi saat ini menuntut kita agar tanggap dengan segala sesuatu yang berhubungan dengan teknologi canggih sebagai alat untuk berkomunikasi. Teknologi akan selalu berkembang dengan cepat dan menimbulkan berbagai pengaruh bagi kehidupan manusia. Telepon pintar merupakan salah satu hasil dari perkembangan teknologi yang paling mutakhir. Dengan menggunakan telepon pintar, kita dapat mengakses berbagai layanan aplikasi yang tersedia untuk chatting atau mengobrol dengan teman, sahabat, guru, maupun orang tua.

Aplikasi instan telah berhasil disukai oleh penduduk dunia, termasuk juga remaja di Indonesia. Indonesia masuk dalam pengguna mobile internet dengan rentang usia paling muda se-Asia Tenggara dengan persentase $21 \%$ pengguna mobile internet di Indonesia tertinggi pada rentang usia 25-35 tahun $(33 \%)$, rentang usia $18-24$ tahun $(32 \%)$, rentang usia di bawah 18 tahun (21\%), dan rentang usia lebih dari 35 tahun (14\%).

Indonesia sudah mulai banyak sekolah-sekolah yang memanfaatkan internet sebagai sarana penting dalam kegiatan pembelajaran. Jumlah pengguna internet di dunia pada tahun 2011 telah mencapai kurang lebih 2 milyar pengguna. Kawasan Asia menyumbang 56\% populasi manusia dari seluruh dunia. Dengan jumlah yang sebanyak itu, mungkin dapat dengan mudah kita simpulkan bahwa pengguna Internet di kawasan Asia juga akan lebih banyak dari kawasan lain di dunia. Asia hanya menyumbang 44.2\% dari keseluruhan jumlah pengguna di seluruh dunia. Atau dengan kata lain dari jumlah estimasi penduduk di 2011 yang sebesar 3.879.740.877 penduduk, hanya 
sejumlah 932.393.209 penduduk yang sudah menjadi pengguna Internet (Nugraha, 2011) Indonesia pun masih kalah dari Malaysia yang berhasil meraih $58.8 \%$ untuk urusan penetrasi pengguna Internet. Tetapi hal yang cukup unik adalah masalah pengguna facebook di Indonesia. Indonesia menjadi negara nomor 1 di Asia dalam hal pengguna facebook. Bisa secara kasar disimpulkan bahwa masyarakat kita cukup antusias dengan konten berbau sosial network di internet. (Measure, 2011)

Hasil penelitian yang dilakukan Pusat Studi Hukum Universitas Islam Indonesia (UII) Yogyakarta, menyebutkan sekitar 15\% dari 202 responden remaja berumur 15-20 tahun sudah melakukan hubungan seks karena terpengaruh oleh tayangan pornoaksi melalui internet, VCD, TV dan bacaan porno. Riset itu juga mengungkapkan 93,5\% remaja sudah menyaksikan VCD porno dengan alasan ingin tahu. Dampak mengakses internet pada situs-situs yang bersifat pornografi dan menonton dapat mempengaruhi perilaku remaja adalah terjadi peniruan yang memprihatinkan. Peristiwa dalam film, video, mengakses langsung memotivasi dan merangsang kaum remaja untuk meniru atau mempraktikkan hal yang dilihatnya.

\section{METODE PENELITIAN}

Penelitian ini menggunakan pendekatan kualitatif, yang digunakan untuk mengetahui sebaran data. (Sugiyono,
2007). Variabel dalam penelitian ini adalah pengetahuan, sikap, kemudahan akses dan biaya dan penggunaan internet dalam pencarian informasi tentang HIV dan AIDS pada remaja.

Subyek penelitian adalah subyek yang memahami informasi obyek penelitian baik sebagai pelaku maupun orang lain yang memahami obyek penelitian, sedangkan informan sekunder adalah orang yang dapat diminta pendapat dan mengerti tentang objek penelitian. Obyek dalam penelitian ini adalah penggunaan internat dalam mencari informasi HIV dan AIDS. Subyek dalam penelitian ini adalah remaja yang mengakses informasi tentang HIV dan AIDS menggunakan media internet minimal dalam 6 bulan terakhir dan bersedia untuk menjadi responden dalam penelitian. Teknik pengambilan sampling dengan purposive sampling.

\section{HASIL DAN PEMBAHASAN}

Hasil Penelitian berdasarkan informasi dari informan diperoleh bahwa mereka mendapatkan informasi tentang HIV dan AIDS dari sekolah, handphone, laptop dan informasi dari teman sebaya. Pemberian informasi oleh pihak luar lebih banyak ditujukan pada kelompok ibu-ibu rumah tangga, belum menyentuh kalangan remaja.

Berdasarkan hasil pengumpulan data, maka karakteristik informan dapat digambarkan dalam tabel sebagai berikut:

Tabel 4.1 Karakteristik responden utama

\begin{tabular}{cll}
\hline No & \multicolumn{1}{c}{ Karakteristik responden } & Jumlah \\
\hline 1 & Jenis Kelamin: & \\
& • Perempuan & 6 orang \\
& • Laki-laki & 4 orang \\
2 & Usia: & \\
& • 16 tahun & 5 orang \\
& - 17 tahun & 3 orang \\
& • 18 tahun & 2 orang \\
3 & Penggunaan media sosial: & \\
& Lama penggunaan & \\
& $\bullet<2$ tahun & 2 orang \\
& - $2-5$ tahun & 8 orang
\end{tabular}




\section{Durasi penggunaan}

- $>2 \mathrm{jam} / \mathrm{hari}$

7 orang

- 1-2 jam/hari

3 orang

Tabel 4.2 Tema penelitian

\begin{tabular}{cl}
\hline No & \multicolumn{1}{c}{ Karakteristik responden } \\
\hline 1 & Pengetahuan tentang HIV dan AIDS \\
2 & Sikap tentang HIV dan AIDS \\
3 & Kemudahan akses dalam pencarian informasi tentang HIV dan AIDS \\
& $\begin{array}{l}\text { Penggunaan internet dalam pencarian informasi tentang HIV dan AIDS pada } \\
\text { remaja }\end{array}$ \\
\hline
\end{tabular}

Menurut informan bahwa HIV merupakan virus yang melemahkan kekebalan tubuh manusia. AIDS merupakan kumpulan gejala penyakit yang timbul akibat virus HIV. HIV disebabkan oleh perilaku seks yang berganti-ganti pasangan, penggunaan narkoba, transfusi darah. Informan mengatakan tidak mengetahui tentang tanda gejala dari penyakit HIV dan AIDS. Upaya pencegahan yang dilakukan dengan tidak berganti-ganti pasangan dan menjauhi narkoba. Seperti yang terlihat dalam kalimat berikut ini:

"...HIV itu virus yang melemahkan kekebalan tubuh manusia. Sedangkan AIDS merupakan kumpulan gejala penyakit yang timbul akibat virus $H I V . .$. penyebab mungkin karena seks bebas,gunain narkoba ... oh ada ada tanda gejalanya ya, malah belum tau .... ya kalau tidak mau tertular ya nggak boleh melakukan hubungan seks dulu sebelum menikah, gak pakai narkobalah aman itu, hidup sehat-sehat saja malah aman ...." (L, 16 th).

Selaian itu menurut informan lain menyatakan bahwa belum mengetahui tentang HIV dan AIDS, baik dari pengertian, faktor penyebab, tanda dan gejalanya. Seperti yang terlihat dalam kalimat berikut ini:

“... HIV dan AIDS itu sama saja ya penyakit menular, ya mungkin karma bagi yang dapat penyakit tersebut, pernah melakukan hal-hal yang tidak benar... gak tau tandanya apa ... menular ya dengan hidup bareng seperti pakai tempat makan yang sama, bersalaman ihh takut kalau deket-deket
... pencegahan jangan melakukan hubungan seksual dulu ...." (H, 16 th).

Menurut informan bahwa mencari informasi tentang HIV dan AIDS di internet setuju, karena dari yang tidak tahu akan menjadi tahu. Mencari informasi merupakan inisiatif sendiri karena memang membutuhkan serta sudah mengetahui manfaatnya. Lebih lanjut informan mengatakan bahwa menggunaan internet dalam pencarian informasi tentang HIV dan AIDS sangat dibutuhkan karena dengan mengetahui cara penularannya akan dapat mencegah dari penyakit tersebut. Disamping itu juga karena masih adanya stigma di masyarakat yang menganggap bahwa HIV dan AIDS adalah penyakit kutukan. Seperti yang terlihat dalam kalimat berikut ini:

"...baguslah untuk cari info apapun termasuk tentang HIV dan AIDS di internet... remaja masa ini cari info ya di internet lah ... ya butuh lah karena dengan internet kita mudah mencari informasi, takut juga sebenarnya dengan HIV dan AIDS." (D, 16 th).

Menurut informan bahwa akses dalam pencarian informasi tentang HIV dan AIDS mudah dan tidak ada hambatan. Media untuk mencari informasi menggunakan handphone dan laptop. Seperti yang terlihat dalam kalimat berikut ini:

“... Mudah tidak harus pergi kemana gitu tinggal searching di internet ... gak ada masalah gampang carinya tapi cuma kadang sinyal susah, gak punya pulsa, tapi gak masalah juga ... cari info dari Hp, laptop ... harga terjangkau karena pakai paketan data 
internet ... kan dapat ilmu juga ...” (J, 17 th).

Menurut informan bahwa awal mula mencari informasi tentang HIV dan AIDS di internet karena inisiatif sendiri. Informasi yang dicari adalah berkaitan dengan tanda gejala, penularan dan pencegahan HIV dan AIDS. Hal tersebut dilakukan karena sudah mendapatkan pelajaran di sekolah akan tetapi belum terlalu jelas, ada rasa sungkan untuk bertanya dan rasa malu. Untuk saat ini mengakses informasi tidak secara rutin akan tetapi ketika ada yang tidak paham saja. Seperti yang terlihat dalam kalimat berikut ini:

“ ... awalnya iseng-iseng saja pengen tau soalnya inisiatif sendiri ... cari-cari tentang penularannya kan ngeri kalau ketularan, tandanya gimana sama biar gak kena harus gimana ... dulu pernah dapat info dari SMP tapi gak terlalu jelas, mau tanya malu, takut diledekin temen, ya cari sendiri saja di internet... tidak rutin mencarinya ketika butuh saja ... (J, 17 th).

Menurut informan lain bahwa belum pernah mencari informasi tentang HIV dan AIDS di internet karena merasa tidak membutuhkan informasi tersebut. Seperti yang terlihat dalam kalimat berikut ini:

“ ...gak pernah cari info di internet, pake internet ya buat cari tugas sekolah, game, youtube sama face book, gak kepikiran cari tentang HIV dan AIDS... (H, 16 th).

\section{PEMBAHASAN}

1. Pengetahuan dalam penggunaan internat dalam pencarian informasi tentang HIV dan AIDS

Pada penelitian ini sebagian besar informan mengatakan bahwa mengetahui pengertian HIV dan AIDS. HIV merupakan virus yang menyebabkan kekebalan tubuh melemah. Sedangkan AIDS adalah kumpulan gejala penyakit yang timbul akibat menurunnya kekebalan tubuh manusia karena diserang oleh HIV. Hal ini sesuai dengan teori bahwa Human Immunodeficiency Virus (HIV) adalah virus yang menyerang sistem kekebalan tubuh manusia dan dapat menimbulkan
Acquired Immune Deficiency Syndrome (AIDS). Acquired Immune Deficiency Syndrome adalah kumpulan gejala yang timbul akibat menurunnya kekebalan tubuh yang disebabkan oleh HIV. Tubuh manusia mempunyai kekebalan untuk melindungi diri dari serangan luar seperti kuman, virus dan penyakit. AIDS melemahkan atau merusak sistem pertahanan tubuh, sehingga akhirnya berdatanganlah berbagai jenis penyakit lain. Acquired Immuno Deficiency Syndrome (AIDS) merupakan kumpulan gejala yang disebabkan oleh retrovirus HIV yang menyerang sistem kekebalan/pertahanan tubuh sehingga menyebabkan kerusakan yang parah dan sejauh ini belum diketahui obatnya. AIDS adalah kependekan dari Acquired Immuno Deficiency Syndrome (sindroma cacat kekebalan tubuh yang didapat), yang merupakan kumpulan gejala-gejala penyakit akibat menurunnya sistem kekebalan tubuh oleh virus yang disebut HIV.

Pengetahuan adalah hasil penginderaan manusia atau hasil tahu seseorang terhadap objek melalui indera yang di milikinya (mata, telinga, hidung dan sebagainya), pengetahuan seseorang termasuk di dalamnya adalah mengenai kesehatan yang di pengaruhi oleh beberapa faktor yaitu pendidikan, paparan media masa, ekonomi atau pendapatan dan hubungan sosial (Notoatmodjo, 2010).

Pengetahuan merupakan hasil tahu dan terjadi setelah orang melakukan penginderaan terhadap suatu obyek tertentu, dari pengalaman dan penelitian terbukti bahwa perilaku yang didasari oleh pengetahuan akan lebih langgeng dari pada perilaku yang tidak didasari oleh pengetahuan (Notoatmodjo, 2007). Hasil penelitian menunjukkan bahwa sebagian kecil informan mengatakan HIV dan AIDS merupakan penyakit "kutukan", karma karena sudah melakukan hal-hal yang tidak sesuai dengan norma. Hal tersebut 
menunjukkan bahwa masih ada anggapan negatif/ stigma di dalam masyarakat/remaja berkaitan dengan penyakit HIV dan AIDS. Hal ini kurang sesuai karena penularan HIV tidak hanya dari hubungan seksual yang tidak aman, melainkan bisa dari penggunaan jarum suntik bergantian, transfuse darah yang terinfeksi HIV dan dari ibu yang mengidap HIV dan AIDS yang ditularkan ke anaknya selama kehamilan, pada proses persalinan maupun pada saat menyusui. Stigma adalah tindakan memberikan label sosial yang bertujuan untuk memisahkan atau mendiskreditkan seseorang atau sekelompok orang dengan cap atau pandangan buruk. Dalam prakteknya, stigma mengakibatkan tindakan diskriminasi yaitu tindakan tidak mengakui atau tidak mengupayakan pemenuhan hakhak dasar individu atau kelompok sesuai dengan manusia yang bermartabat (Monjok et al, 2010). Stigma tentang HIV masih terjadi di masyarakat yang merupakan salah satu hambatan dalam penanggulangan HIV/AIDS (Kemenkes, 2012).

Stigma terjadi karena adanya persepsi bahwa mereka di anggap sebagai "musuh", "penyakit", "elemen masyarakat yang memalukan", atau "mereka yang tidak taat terhadap norma masyarakat dan agama yang berlaku". Implikasi dari stigma bukan hanya pada diri orang atau kelompok tertentu tetapi juga pada keluarga dan pihak-pihak terkait (Monjok et al, 2010). Stigma ini berawal dari penularan pertama kali ditemukan di Indonesia pada kaum homoseksual di Bali.

Tindakan menstigma atau stigmatisasi terjadi melalui beberapa proses yang berbeda-beda seperti, stigma aktual yaitu stigma yang di alami yaitu jika ada orang atau masyarakat yang melakukan tindakan nyata, baik verbal maupun non verbal yang menyebabkan orang lain di bedakan, Stigma potensial atau yang di rasakan (felt) yaitu jika tindakan stigma belum terjadi tetapi ada tanda atau perasaan tidak nyaman, sehingga orang cenderung tidak mengakses layanan kesehatan, Stigma internal yaitu seseorang menghakimi dirinya sendiri sebagai "tidak berhak", "tidak di sukai masyarakat". Proses stigma tidak bersifat tunggal, bebrapa proses tersebut dapat terjadi secara bersamaan dan dapat bersifat stigmatisasi ganda, misalnya "pengguna narkoba suntik (penasun)" (Parker dan Aggleton, 2002).

Semua responden mengatakan belum mengetahui tentang tanda dan gejala dari penyakit HIV dan AIDS. Hal tersebut terlihat dari jawaban responden yang mengatakan bahwa dengan hidup bersama dengan penderita HIV dan AIDS seperti menggunakan tempat makan bersama-sama dengan penderita HIV dan AIDS, bersalaman dapat tertular dengan penyakit tersebut. Sehingga remaja cenderung menghindari penderita HIV dan AIDS untuk menjaga diri dari tertular penyakit tersebut. Dengan remaja yang tidak mengetahui tentang tanda dan gejala dari penyakit HIV dan AIDS membuat mereka menstigma orang dengan HIV dan AIDS.

Pengetahuan tentang HIV/AIDS dapat didapatkan melalui media informasi yang menjadi perantara dalam menyampaikan informasi, merangsang pemikiran dan kemampuan serta menambah pengetahuan. Sumber informasi dapat di peroleh melalui media cetak (surat kabar, majalah, buku), media elektronik (televisi, radio, internet). Akibatnya, seseorang yang lebih sering terpapar media massa akan memperoleh informasi lebih banyak dibanding orang yang tidak terpapar media massa. Ini berarti, paparan media massa mempengaruhi tingkat pengetahuan seseorang.

Penelitian Babalola et al (2009) dalam Annisa (2014) menemukan bahwa 
paparan seseorang terhadap media informasi meningkatkan pengetahuan tentang HIV. Pengetahuan HIV berhubungan dengan sikap dalam menerima seseorang yang terserang virus HIV. Berdasarkan hasil penelitian menunjukkan bahwa peluang pemberian informasi atau peningkatan pengetahuan remaja tentang HIV dan AIDS sangat bias diberikan menggunakan media social atau internet.

2. Sikap dalam penggunaan internat dalam pencarian informasi tentang HIV dan AIDS

Pada penelitian ini semua informan mengatakan bahwa mendukung upaya mencari informasi tentang HIV dan AIDS di internet, karena dengan mencari informasi dari yang tidak tahu akan menjadi tahu. Lebih lanjut informan mengatakan bahwa menggunaan internet dalam pencarian informasi tentang HIV dan AIDS sangat dibutuhkan karena dengan mengetahui cara penularannya akan dapat mencegah dari penyakit tersebut. Disamping itu juga karena masih adanya stigma di masyarakat yang menganggap bahwa HIV dan AIDS adalah penyakit kutukan.

Sikap merupakan kecenderungan untuk bertindak, untuk bereaksi terhadap rangsangan, oleh karena itu manifestasi sikap tidak dapat langsung terlihat, akan tetapi harus ditafsirkan terlebih dahulu sebagai tingkah laku yang masih tertutup. Sikap yang baik adalah sikap yang didasari oleh pengetahuan dan kesadaran sehingga akan tercermin perilaku yang baik pula.

Sikap adalah keadaan mental dan saraf dari kesiapan, yang diatur melalui pengalaman yang memberikan pengaruh dinamik atau terarah terhadap respon individu pada semua obyek dan situasi yang berkaitan dengannya. Sikap itu dinamis, tidak statis (Notoatmodjo, 2010). Sikap adalah kesiapan merespon yang sifatnya positif atau negatif terhadap obyek atau situasi secara konsisten. Apabila individu memiliki sikap yang positif terhadap suatu obyek, ia akan siap membantu, memperhatikan, berbuat sesuatu yang menguntungkan obyek itu. Sebaliknya, bila ia memiliki sikap yang negatif terhadap suatu obyek, maka dia akan mengecam, mencela, menyerang, bahkan membinasakan obyek itu (Azwar, 2016). Tiga komponen sikap dijelaskan Notoatmodjo, yaitu: Kepercayaan (keyakinan), ide, dan konsep terhadap suatu obyek, Kehidupan emosional atau evaluasi terhadap suatu obyek dan Kecenderungan untuk bertindak (tend to behave) (Notoatmodjo, 2010).

3. Kemudahan akses dalam pencarian informasi tentang HIV dan AIDS

Menurut informan bahwa akses dalam pencarian informasi tentang HIV dan AIDS mudah dan tidak ada hambatan. Media untuk mencari informasi menggunakan handphone dan laptop.

Kondisi yang membuat seseorang mampu melakukan pemanfaatan pelayanan kesehatan. Termasuk dalam komponen ini adalah sumber daya yang dimiliki keluarga maupun masyarakat, misalnya tingkat pendapatan (status ekonomi), keikutsertaan dalam program asuransi kesehatan, ketersediaan petugas yang dapat memberikan pelayanan, biaya dan jarak pelayanan kesehatan dengan rumah berpengaruh terhadap pemanfaatan pelayanan kesehatan termasuk untuk mencari informasi.

Menurut informan bahwa biaya untuk pencarian informasi tentang HIV dan AIDS di internet relatif terjangkau karena biaya yang dikeluarkan sebanding dengan ilmu yang diperoleh. Kondisi yang membuat seseorang mampu melakukan pemanfaatan pelayanan kesehatan. Termasuk dalam komponen ini adalah sumber daya yang dimiliki keluarga maupun masyarakat, misalnya tingkat pendapatan (status 
ekonomi), keikutsertaan dalam program asuransi kesehatan, ketersediaan petugas yang dapat memberikan pelayanan, biaya terhadap pemanfaatan pelayanan kesehatan.

4. Penggunaan internet dalam pencarian informasi tentang HIV dan AIDS pada remaja

Umumnya media sosial merujuk pada alat komunikasi antar manusia dimana mereka dapat menciptakan, berbagi, dan bertukar informasi dalam jaringan internet (networks). Selain itu, media sosial juga diartikan sebagai sebuah bentuk komunikasi yang bermediasikan komputerisasi, seperti email dan percakapan online yang memungkinkan pengguna untuk bertukar konten melalui internet (Collins, 2014).

Menurut informan bahwa awal mula mencari informasi tentang HIV dan AIDS di internet karena inisiatif sendiri. Informasi yang dicari adalah berkaitan dengan tanda gejala, penularan dan pencegahan HIV dan AIDS. Hal tersebut dilakukan karena sudah mendapatkan pelajaran di sekolah akan tetapi belum terlalu jelas, ada rasa sungkan untuk bertanya dan rasa malu. Untuk saat ini mengakses informasi tidak secara rutin akan tetapi ketika ada yang tidak paham saja.

Hasil penelitian tentang penggunaan internet menunjukkan bahwa jumlah dari 10 responden yang menyatakan menggunakan internet paling lama antara 2-5 tahun yang lalu yaitu sebanyak 8 responden $(80 \%)$, durasi penggunaan lebih dari 2 jam/hari. Penggunaan internet secara aktif yakni sebanyak 6 responden $(60 \%)$ dikarenakan perempuan lebih fokus pada kemampuan untuk meningkatkan kualitas hidup, dibandingkan laki-laki yang hanya melihat spesifikasi teknis secara teknologi saja. Selain itu juga, Sheldon (2008) menemukan bahwa perempuan lebih menyukai media sosial untuk bersosialisasi menjalin hubungan dengan keluarga, dan teman-teman, melewatkan waktu, dan hiburan, akan tetapi laki-laki lebih menyukai menggunakan media sosial untuk bertemu dengan orang yang baru.Hal ini sesuai dengan hasil survei yang dilakukan oleh Asosiasi Penyelenggara Internet Indonesia (APJII) tahun 2016, tentang anak-anak Indonesia yang mulai bersentuhan dengan internet yaitu sebanyak 768 ribu pengguna dengan rentan usia 10-15 tahun, media sosial merupakan salah satu jenis konten internet yang paling tinggi diakses dari jenis konten internet lainnya yaitu mencapai 97,4\% pengguna (Ngazis dan Haryanto, 2016), dengan demikian dapat dismpulkan bahwa para siswa tersebut sudah mulai menggunakan media sosial sejak berumur 10 tahun dikarenakan media sosial tersebut mudah diakses bahkan oleh anak-anak dibawah umur.

Penelitian ini menunjukkan bahwa di sektor gender sebagian besar penggunaan media sosial secara aktif adalah perempuan yaitu sebanyak 6 responden (60\%). Hasil riset APJII dan PusKaKom UI ini di sektor gender pada tahun 2014 lalu mengemukakan pengguna media sosial di Indonesia lebih didominasi oleh perempuan yaitu tercatat $51 \%$ pengguna (Maulana, 2015). Hal ini menunjukkan bahwa perempuan lebih dominan menggunakan media sosial dibandingkan dengan laki-laki dikarenakan perempuan lebih fokus pada kemampuan untuk meningkatkan kualitas hidup, berbeda halnya dengan laki-laki yang melihat spesifikasi teknis secara teknologi saja.

Sesuai dengan teori Azwar (2016) yang menunjukkan bahwa media sosial merupakan salah satu pengaruh besar dalam pembentukan opini dan kepercayaan orang, dengan adanya media sosial yang membawakan informasi akan memberikan dasar afektif dalam menilai suatu hal sehingga terbentuklah arah sikap 
tertentu. Responden yang mendapatkan informasi dari media sosial dengan kategori pengguna berat dapat dikarenakan akses media sosial pada remaja sekarang ini semakin mudah. Media sosial merupakan salah satu alat atau perantara yang modern digunakan oleh seseorang untuk berinteraksi dan berkomunikasi tanpa adanya hambatan dan penghalang seperti batasan umur, jenis kelamin, jenis pekerjaan ataupun batasan negara, sehingga menjadi daya tarik bagi remaja dalam menggunakan media sosial karena tidak terbatas dengan apapun.

Semakin lama responden menggunakan internet, maka semakin aktif pula penggunaanya. Penelitian ini sejalan dengan penelitian yang dilakukan oleh Aprinta dan Dwi (2017) bahwa ada hubungan yang positif antara intensitas penggunaan media sosial dengan tingkat kepekaan sosial di kalangan remaja, yang artinya semakin sering remaja mengakses media sosial, maka semakin sering pula ia akan mencari informasi menggunakan media sosial, sehinggga ia aktif dalam berinteraksi menggunakan media sosial tersebut.

\section{SIMPULAN}

1. Pengetahuan tentang HIV dan AIDS Pengetahuan tentang HIV dan AIDS masih kurang dimana didapatkan hasil bahwa sebagian besar informan mengetahui pengertian dan cara pencegahan dari HIV dan AIDS. Sebagian besar responden belum mengetahui tentang tanda gejala dan cara penularan dari HIV dan AIDS.

2. Sikap dalam penggunaan internat dalam pencarian informasi tentang HIV dan AIDS

Semua informan mengatakan mendukung/ setuju dalam pencarian informasi tentang HIV dan AIDS melalui media internet

3. Kemudahan akses dalam pencarian informasi tentang HIV dan AIDS
Semua informan mengatakan akses dalam pencarian informasi tentang HIV dan AIDS sangatlah mudah, biaya dalam pencarian informasi tentang HIV dan AIDS terjangkau dan sepadan dengan ilmu yang diperoleh.

4. Penggunaan internet dalam pencarian informasi tentang HIV dan AIDS pada remaja

Semua informan mengatakan menggunakan internet atas inisiatif sendiri, sebagian besar informan mengatakan menggunakan internet kurang lebih 2-5 jam perhari, rata-rata menggunakan internet sejak lebih dari 2 tahun yang lalu. Sebagian besar responden mengatakan sudah pernah mencari informasi mengenai HIV dan AIDS walaupun tidak intens hanya apabila mereka membutuhannya.

\section{DAFTAR PUSTAKA}

Aprianta, G.E.B., dan Dwi, E.S.W. (2017). Hubungan Penggunaan Media Sosial dengan Tingkat Kepekaan Sosial di Usia remaja. The Messenger. Vol 9 (1).

Arikunto, S. Prosedur Penelitian Suatu Pendekatan Praktik. Jakarta: Rineka Cipta.

Azwar, S. (2016). Sikap Manusia, Teori dan Pengukurannya. Yogyakarta: Pustaka Pelajar.

Collins, F.M. (2014). The Relationship Between Social Media and Empathy. Collage of Graduate Studies (COGS). Georgia Southern University.

Dewi, H.E. 2012. Memahami Perkembangan Fisik Remaja. Yogyakarta: Gosyen Publising.

Dwianjani, Maria. 2016. Penderita HIV/AIDS Kini Didominasi Remaja dan Ibu-ibu. http://kabarhandayani.com/penderit a-hivaids-kini-didominasi-remajadan-ibu-ibu/. Diakses 9 Juni 2017. 
Hurlock, E. 2010. Psikologi Perkembangan. Jakarta: Erlangga

Kemenkes RI. 2010. Laporan Perkembangan Tri wulan 1 (Januari - Maret) tahun 2016. Jakarta : Direktorat Jenderal Pencegahan dan Pengendalian Penyakit Kemenkes RI.

2011. Pedoman Nasional Manajemen Program HIV dan AIDS. Jakarta : Direktorat Jenderal Pengendalian Penyakit dan Penyehatan Lingkungan.

Data Internet Indonesia, Pengguna Anakanak Mengejutkan dalam http://viva.co.id, diperoleh tanggal 22 Juni 2018

Notoatmodjo, S. 2010. Ilmu Perilaku Kesehatan. 2010, Jakarta: Rineka Cipta.

.2010. Metodologi Penelitian Kesehatan. Jakarta: Rineka Cipta.

.2012. Promosi kesehatan dan ilmu prilaku. Jakarta : Rineka Cipta.

Nugraha F. Data Pengguna Internet di Kawasan Asia dan Indonesia. Tekno. :http:www.mobile.go.id diakses 12 Agustus 2017.

Purwantom, D. 2003. Komunikasi Bisnis. III, editor. Jakarta: Erlangga.

Wawan\& Dewi. 2010. Pengetahuan, Sikap dan Perilaku Manusia. Yogyakarta: Nuha Medika
KPA. 2008. Pedoman Prosedur Pelaksanaan Program Pengurangan Dampak Buruk Bagi Pengguna NAPZA Suntik di Puskesmas. Jakarta: KPA.

Maulana, A. (2015). Pengguna Internet Indonesia di Dominasi Remaja dan Wanita, dalam https://www.liputan6.com, diakses tanggal 29 juni 2018.

Measure. E. 2010. Pengguna Internet mobile. Tekno.

Ngaziz, A.N. dan Haryanto, A.T. (2016).

Sheldon, P. (2008). Student Favorite: Facebook and Movies for It Use. Southern Mass Communication Jurnal Spring.

Sopiyudin, D. 2014. Statistik untuk Kedokteran dan Kesehatan. Jakarta: Epidemiologi Indonesia.

Sugiyono. 2015. Metode Penelitian Kuantitatif Kualitatif dan R\&D. Bandung: Alfabeta.

Sulistyaningsih. 2011. Metodologi Penelitian Kebidanan KuantitatifKualitatif. Yogyakarta: Graha Ilmu.

Tukiran. 2010. Keluarga Berencana dan Kesehatan Reproduksi. Yogyakarta: Nuha Medika. 